\title{
Willingness to Buy New Ethnic Produce Items: A Study of Latino Consumers from Mexico and Puerto Rico in the Eastern United States
}

\author{
Ramu Govindasamy ${ }^{1,3,6}$, Venkata S. Puduri ${ }^{1,4}$, \\ and James E. Simon ${ }^{2,5}$
}

\begin{abstract}
ADDITIONAL INDEX WORDs. food habits, specialty crops, fresh produce, logit model, Latino populations

SUMMARY. The purpose of this study was to predict Latinos', consumers from Mexico and Puerto Rico, willingness to buy ethnic produce recently introduced or new to market. Specifically, we analyzed and compared socioeconomic characteristics of 542 Mexican and Puerto Rican consumers and expressed value judgments on their willingness to buy ethnic produce that has been recently introduced or new to market. This study was based on a primary data set collected from interviewing 542 Latino consumers (Mexico and Puerto Rico origin). A bilingual questionnaire was prepared in Spanish and English for Mexicans and Puerto Ricans in 16 states (Connecticut, Delaware, Florida, Georgia, Maine, Maryland, Massachusetts, New Hampshire, New Jersey, New York, North Carolina, Pennsylvania, Rhode Island, South Carolina, Vermont, and Virginia) and Washington, DC. Attributes that contributed toward willingness to buy new ethnic produce include respondent's expenditure on total produce and ethnic produce, perceptions such as the importance of store availability, language, willingness to buy locally grown, organic, genetically modified, and country of origin labeled produce items. This information will assist market intermediaries and farmers better understand Latino consumers' (Mexico and Puerto Rico group) perceptions and factors that drive willingness to buy ethnic produce that is recently introduced or new to market.
\end{abstract}

$\mathrm{E}$ thnic markets consist of specialty products and services that target specific ethnic community within a society and satisfy their needs on the basis of tradition and sociocultural values. These products include specialty foods, fruit, vegetables, and herbs that are not traditionally grown or sold in the mainstream markets, but are imported and are currently grown on a limited scale in the local geographical region. Specialty vegetables are also referred to as exotic, unusual, world vegetables, and/

\footnotetext{
This project was supported by the National Research Initiative of the National Institute of Food and Agriculture, USDA, Grant number 2005-35618-15735 and the Specialty Crop Research Initiative of the National Institute of Food and Agriculture, USDA, Grant number 2009-51181-06035.

${ }^{1}$ Department of Agricultural, Food and Resource Economics, Rutgers, The State University of New Jersey, New Brunswick, NJ 08901

${ }^{2}$ Department of Plant Biology and Plant Pathology, Rutgers, The State University of New Jersey New Brunswick, NJ 08901

${ }^{3}$ Associate Professor.

${ }^{4}$ Research Associate.

${ }^{5}$ Professor and Director of the New Use Agriculture and Natural Plant Products Program.

${ }^{6}$ Corresponding author. E-mail: govindasamy@aesop.
} rutgers.edu. or high-value crops (Bhugra, 1999). Specialty and ethnic crops defined as vegetables/fruits/herbs with unique characteristics that are imported to the United States, and/or currently grown on a limited scale in the United States, are usually targeted toward a specific ethnic population with strong preference for ethnic cuisines [e.g., habanero pepper (Capsicum chinense), calabaza (Cucurbita moschata), and tomatillo (Physalis philadelphica)] (Govindasamy et al., 2007b).

Success in commercial farming in the east will depend largely on the ability of the commercial growers to focus on high-value, specialty crops such as ethnic produce targeted at specific niche markets for favorable competitive advantages (Govindasamy et al., 2006; Tubene, 2001). Recent immigrant communities enjoy a strong bond to their cultures and ethnic cuisines. Asp (1999) argues that food decisions are made by consumers based on cultural factors, psychological factors, lifestyle factors, and food trends. In many communities, food is an integral part of the culture and there is an established linkage between food and culture (Bhugra, 1999). The type of food cooked, patterns of purchasing produce, and amount spent on food are very centric to and dependent on cultural trends. Many ethnic communities have their own channels of produce distribution outside the traditional retail supermarket industry and few studies have studied this informal and growing industry and its consumer base. The growing ethnic population on the eastern United States is changing the demand for fresh produce available in markets (Govindasamy et al., 2007b).

As ethnic demographic profiles change, fresh produce marketers and commercial growers aware of such trends may be able to alter or add to their selection of crops to effectively respond to new trends and changes in demand (Govindasamy et al., 2007a). According to 2001 Census Bureau report, Hispanics (to whom we refer as Latinos) and Asians continue to be the two fastest growing minorities in the United States. The overall U.S. average population increased $13 \%$ between 1990 and 2000 compared with 58\% Latinos during the same period, making it the fastest growing minority group in the United States (Guzman, 2001; Perry and Mackum, 2001). The Latino population is projected to nearly triple from 49.7 to 132.8 million during the period from 2010 to 2050 (U.S. Census Bureau, 2008). Among Latinos in the United States, $65 \%$ were of Mexico origin, $9 \%$ were of Puerto Rico origin, $3.5 \%$ were of Cuban, $3.3 \%$ were of Salvadoran, $3.3 \%$ were of Dominican, and the remaining were of other central American, South American, or other Latino origin (U.S. Census Bureau, 2009). Among Latinos, $\approx 14.2$ million people were foreign born compared with 37.2 million overall U.S. foreignborn populations. In terms of Latino ethnic subgroups, 8.6 million Mexicans were foreign born, whereas only 47,130 Puerto Ricans were foreign born. Majority of the Mexicans were immigrants compared with Puerto Ricans. On the basis of the high concentration, Mexican and Puerto Rican subgroups were selected within Latino population for this study. Among the Latino populations in the eastern United States, Puerto Ricans are concentrated in New York $(1,050,293)$, Florida $(482,027)$, New Jersey $(366,788)$, Pennsylvania $(228,557)$, Massachusetts $(199,207)$, Connecticut $(194,443)$, and Virginia $(41,131)$, whereas, Mexicans are concentrated in Florida $(363,925)$, Georgia 
$(275,288)$, New York $(260,889)$, North Carolina $(246,545)$, New Jersey $(102,929)$, Virginia $(73,979)$, Pennsylvania $(55,178)$, and South Carolina $(52,871)$. Overall, $\approx 2.7$ million Puerto Ricans and 1.6 million Mexicans are living in the eastern United States (Table 1).

Gauging ethnic consumer attitudes on any subject is a difficult process. If a new produce item is deemed to be as safe as current produce in the shelves and it is readily recognized with appropriate labeling, its success in the marketplace will be decided by consumers. This study adds to the ethnic food marketing literature by examining consumers' willingness to buy ethnic produce that is recently introduced or new to the market. Specifically, results generated may be useful to food retailers to target consumers who are willing to buy new products or newly introduced ethnic produce items.

\section{Data}

This study was based on a telephone survey and the data were collected from interviewing Latino consumers. A survey questionnaire was prepared in bilingual language and conducted in English and Spanish for Latino ethnic subgroups including Mexicans and Puerto Ricans in 16 states (Connecticut, Delaware, Florida, Georgia, Maine, Maryland, Massachusetts, New Hampshire, New Jersey, New York, North Carolina, Pennsylvania, Rhode Island, South Carolina, Vermont, and Virginia) and
Washington, DC. Using random sampling, 271 individual households were interviewed from each ethnic subgroup (Mexican and Puerto Rican) totaling of 542. Telephone survey was conducted by The Wats Room (Rochelle Park, New Jersey), a market research company, and the random sample was drawn from their database, which was compiled from various sources including public phone directories, secretaries of state, county courthouses, public record notices, etc., between Apr. and May 2006. The phone-administered questionnaires were completed by the principal grocery shopper in each household and belonged to the ethnic groups of interest, as identified by each respondent with prompting from the interviewer. Interviews were conducted using the computer-assisted telephone interviewing system with interview times averaging between 15 and $20 \mathrm{~min}$, depending on ethnic group.

\section{Model framework}

The objective of this study was to predict the influence of Latino consumers' socioeconomic attributes on willingness to buy ethnic produce that is recently introduced or new to the market. The respondents were asked whether they were willing to buy ethnic produce that had been recently introduced or is new to their market, and on the basis of this, a logit model was developed to predict the willingness to buy new ethnic produce items. As for

Table 1. Statewide distribution of Mexico and Puerto Rico origin populations in eastern United States based on 2000 Census data (U.S. Census Bureau, 2001).

\begin{tabular}{lrr}
\hline State & Mexican (no.) & Puerto Rican (no.) \\
\hline Connecticut & 23,484 & 194,443 \\
Delaware & 12,986 & 14,005 \\
District of Columbia & 5098 & 2,328 \\
Florida & 363,925 & 482,027 \\
Georgia & 275,288 & 35,532 \\
Maine & 2,756 & 2,275 \\
Maryland & 39,900 & 25,570 \\
Massachusetts & 22,288 & 199,207 \\
New Hampshire & 4,590 & 6,215 \\
New Jersey & 102,929 & 366,788 \\
New York & 260,889 & $1,050,293$ \\
North Carolina & 246,545 & 31,117 \\
Pennsylvania & 55,178 & 228,557 \\
Rhode Island & 5,881 & 25,422 \\
South Carolina & 52,871 & 12,211 \\
Vermont & 1,174 & 1,374 \\
Virginia & 73,979 & 41,131 \\
Total & $1,549,761$ & $2,718,495$ \\
\hline
\end{tabular}

the model specification, the binary dependent variable was defined as one if the respondent was willing to buy ethnic produce that is recently introduced or new to market, otherwise zero. This study analyzes consumers' likelihood of willingness to buy ethnic produce that has been recently introduced or new to the market to take advantage of such a scenario within the random utility discrete choice framework.

Following the random utility framework, every consumer faces a choice between willing to buy ethnic produce that is recently introduced or new to the market (dependent variable) and otherwise. The logit model was selected because of its asymptotic characteristics that constrain the predicted probabilities to a range of zero to one. Additionally, the logit model is favored given its mathematical simplicity and is often used in a setting where the dependent variable is binary. The estimation method uses the maximum likelihood estimation procedures characterized as they provide consistent parameter estimates that are asymptotically efficient (Gujarati, 1992; Pindyck and Rubinfeld, 1991).

The relationship between dependent variable and socioeconomic characteristics is explored by modeling the indicator variable $Z_{i}$ for the $i$ th consumer as a function of his/her socioeconomic characteristics as follows:

$$
\begin{aligned}
Z_{i}= & \beta X_{i}=\beta_{0}+\beta_{1} x_{i 1}+\beta_{2} x_{i 2}+\ldots \\
& +\beta_{k} x_{i k}+v_{i}, \quad i=1,2, \ldots, n,
\end{aligned}
$$

where $x_{i j}$ denotes the jth socioeconomic attribute of the ith respondent, $\boldsymbol{\beta}=\left(\beta_{0}, \beta_{1}, \ldots, \beta_{k}\right)$ is the parameter vector to be estimated and $v_{i}$ is the random error or disturbance term associated with the $i$ th consumer. Under the logistic distributional assumption for the random term, the probability $P_{i}$ can be now be expressed as:

$$
\begin{aligned}
P_{i} & =F\left(Z_{i}\right)=F\left(\beta_{0}+\sum_{j=1}^{k} \beta_{j} x_{i j}\right) \\
& =F\left(\beta X_{i}\right)=\frac{1}{1+\exp \left(-\beta X_{i}\right)} .
\end{aligned}
$$

The estimated $\beta$-coefficients of Eq. [2] do not directly represent the marginal effects of the independent variables on the probability $P_{\mathrm{i}}$. In the case of a continuous explanatory variable, the marginal effect of $x_{j}$ on the probability $P_{i}$ is given by: 


$$
\begin{gathered}
\partial P_{i} / \partial x_{i j}=\left[\beta_{j} \exp \left(-\beta X_{i}\right)\right] / \\
{\left[1+\exp \left(-\beta X_{i}\right)\right]^{2} .}
\end{gathered}
$$

However, if the explanatory variable is qualitative or discrete in nature $\partial P_{i} / \partial x_{i j}$ does not exist. In such a case, the marginal effect is obtained by evaluating $P_{i}$ at alternative values of $x_{i j}$. For example, in the case of a binary explanatory variable $x_{i j}$ that takes values of 1 and 0 , the marginal effect is determined as:

$$
\partial P_{i} / \partial x_{i j}=P\left(x_{i j}=1\right)-P\left(x_{i j}=0\right) .
$$

The following empirical model is specified to capture the relationship between consumers' socioeconomic variables and willingness to buy ethnic produce that is recently introduced or new to the market.

The model was formulated as:

$$
\begin{aligned}
& \text { New_prod }=\beta_{0}+\beta_{1} \text { Eth_prod_exp } \\
& +\beta_{2} \text { Tot_prod_expend }+\beta_{3} \text { Buy_eth_amer } \\
& +\beta_{4} \text { Store_avbl_imp }+\beta_{5} \text { Lang_imp } \\
& +\beta_{6} \text { Price_imp }+\beta_{7} \text { Selection_better } \\
& +\beta_{8} \text { Local_grown }+\beta_{9} \text { Org_grown } \\
& +\beta_{10} \text { Gm_prod }+\beta_{11} \text { Cool_prod } \\
& +\beta_{12} \text { Urban }+\beta_{13} \text { Family_size } \\
& +\beta_{14} \text { Less_12grade }+\beta_{15} \text { Hschool_grad } \\
& +\beta_{16} \text { Married }+\beta_{17} \text { Mexican } \\
& +\beta_{15} \text { Hschool_grad }+\beta_{16} \text { Married } \\
& +\beta_{17} \text { Mexican. }
\end{aligned}
$$

The vector of explanatory variables used in the model included socioeconomic and demographic characteristics of the Latino consumers and variables related to consumers' perceptions and motivation. The sociodemographic characteristics of Latino consumers included in Eq. [1] were expected to be similar to those influencing consumer expenditures on fruit and vegetables in general (Nayga, 1995) and those included in other analyses of consumer preferences for local products (Jekanowski et al., 2000). Robinson and Smith (2002) also found that the psycho-social and demographic variables influence the consumer intention to purchase sustainably produced foods. In addition, consumer perceptions and motivations toward willingness to buy new produce items were also hypothesized to influence their choice.

The variables used in the model are further explained in Table 2.

\section{Logit model analysis}

SUMMARY OF EXPLANATORY VARIABLES. Explanatory variables that were used in the model to predict which consumers are willing to buy ethnic produce that is recently introduced or new to the market are presented in Table 2. In total, $54 \%$ of Latino consumers were willing to buy ethnic produce that is recently introduced or new to market (New_prod) and the remaining $46 \%$ of them were not. More than half of those responded (57\% for Mexicans; $51 \%$ for Puerto Ricans) were willing and interested in purchasing new ethnic produce. On average, each respondent's family spent (Eth_prod_exp) $\approx \$ 78$ per month on ethnic produce. Monthly average expenditure by Mexicans (\$79) on ethnic produce was only \$2 more than Puerto Ricans (\$77). Latino households spend an average of $\approx \$ 116$ per month on total produce (Tot prod_exp), whereas Puerto Ricans (\$123) spend more than Mexicans (\$109). Around 28\% of Latino respondents purchased all ethnic produce from typical (or traditional) American stores (Buy_eth_amer). Within the subgroups, Mexicans (31\%) were found to purchase more of their ethnic product from a traditional American grocery store or supermarket than Puerto Ricans (25\%). In terms of respondents' decision to shop at ethnic produce store, $68 \%$ of them preferred store availability (Store_avbl_imp), 40\% favored shopping in stores where employees spoke Spanish, what we define as having ethnic language service in store (Lang_imp), and 62\% of those surveyed indicated that price is very important (Price_imp). Interestingly, considering the size and layout of larger supermarkets, $\approx 47 \%$ of respondents indicated that the selection of fruit and vegetables is better in ethnic outlets compared with conventional establishments (Selection_better).

Seventy-eight percent of respondents were willing to buy locally grown (Local_grown) ethnic produce items. Around 56\% of respondents were willing to buy organically grown ethnic produce (Org_grown), whereas, among surveyed respondents, only $12 \%$ of them were willing to buy genetically modified produce items (Gm_prod). We found that $47 \%$ of Latino respondents were willing to buy country of origin labeled (COOL) ethnic produce items
(Cool_prod) (see Table 2). In terms of Latino subgroup results, more Puerto Ricans $(50 \%)$ were willing to buy COOL produce items than their Mexican (44\%) counterparts.

Among respondents, 39\% of them were residing in urban areas (Urban), with more Puerto Ricans (46\%) residing in urban areas than Mexicans (32\%). The average Latino survey respondent's family size was 3.86 persons (Family size). Among Latino respondents, 89\% had an education of 12 th grade or higher(Less_12grade) and 34\% of them graduated from high school (Hschool_ grad). There was a slightly higher percentage of Puerto Ricans (38\%) who graduated from high school than Mexicans $(31 \%)$. About $61 \%$ of Latino respondents were married (Married), of which, $71 \%$ of Mexicans and $52 \%$ of Puerto Ricans were married.

Some of the variables tested in this model showed statistically significant differences between the means of Mexican and Puerto Rican ethnicities. The variables New_prod, Selection_Better, Urban, Less_12grade, Hschool_Grad, and Married showed statistically significant differences between the Mexican and Puerto Rican respondents ranging from $1 \%$ to $10 \%$ significant level (Table 2).

Model Results. Results from the logit model explain Latino ethnic consumers' willingness to buy ethnic produce that is recently introduced or new to the market. The model correctly predicted the outcome of the dependent variable in $71.03 \%$ of total observations (Table 3 ). The $\chi^{2}$ statistics rejected the null hypothesis that the explanatory variables as a set were insignificant in explaining variations in the dependent variable at 0.001 level and the McFadden's $R^{2}$ was 0.16 . The $\chi^{2}$ value was 120.97 with $17 \mathrm{df}$.

Of the 17 explanatory variables used in the logit model, nine were significant. Among Latinos a significant number of Mexicans were willing to buy ethnic produce that was recently introduced or new to the market. As the model results indicated (Table 4), Mexican respondents' expenditure on total produce and ethnic produce, perceptions such as the importance of store availability, language, willingness to buy locally grown, organic, genetically modified, and COOL produce items influenced their willingness to buy ethnic produce that is recently 
Table 2. Mean, percentage distributions, and SD of ethnic Mexico and Puerto Rico origin populations' attributes definitions (e.g., expenditure on total and ethnic produce, consumer perceptions, urban, family size, education, marital status, and ethnicity) that are used in logit model to predict who is willing to buy new ethnic produce item. Data collected via telephone survey conducted in the eastern United States between Apr. and May 2006.

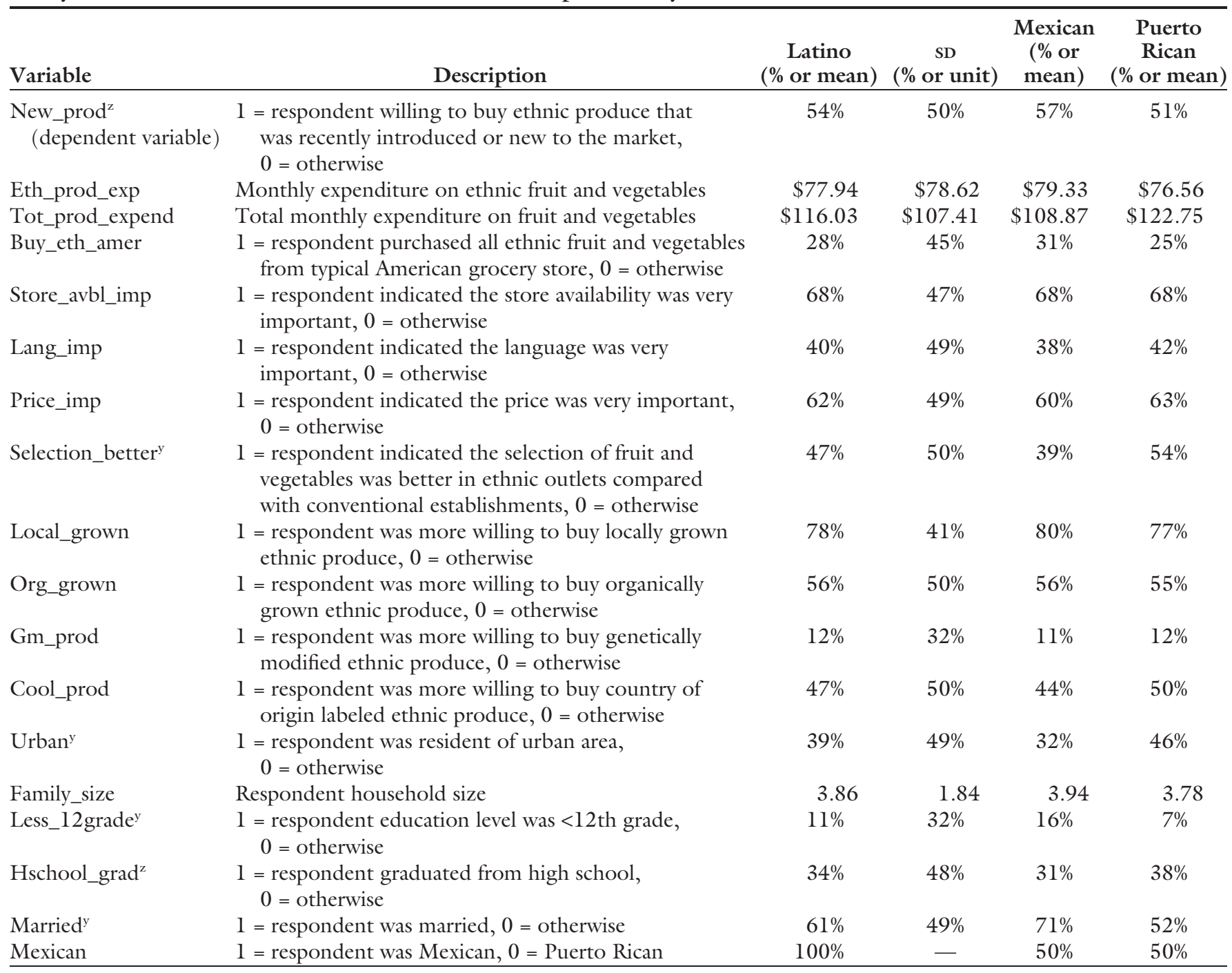

${ }^{2}$ Significant at $P \leq 0.10$.

${ }^{\text {y }}$ Significant at $P \leq 0.01$.

Table 3. Overall predictive accuracy of logit model with prediction success of ethnic Mexico and Puerto Rico origin populations' willingness to buy new ethnic produce items based on attributes (e.g., expenditure on total and ethnic produce, consumer perceptions, urban, family size, education, marital status, and ethnicity). Data collected via telephone survey conducted in the eastern United States between Apr. and May 2006.

\begin{tabular}{lrrr}
\hline & \multicolumn{2}{c}{ Predicted } & \\
\cline { 2 - 3 } Actual value & \multicolumn{1}{c}{$\mathbf{0}$} & \multicolumn{1}{c}{$\mathbf{1}$} & Total \\
\hline 0 & $164(30.3 \%)$ & $83(15.3 \%)$ & $247(45.6 \%)$ \\
1 & $74(13.7 \%)$ & $221(40.8 \%)$ & $295(54.4 \%)$ \\
Total & $238(43.9 \%)$ & $304(56.1 \%)$ & $542(100.0 \%)$ \\
\hline
\end{tabular}

introduced or new to market compared with Puerto Rican consumers.

Those spending more per month on total produce were more likely to buy ethnic produce that was recently introduced or new to the market.
Unlike the other variables discussed in this section, average monthly total produce expenditure is a continuous variable, and the change in probability can be interpreted as follows. For every additional dollar spent on total produce per month, the likelihood of buying recently introduced or new to the market products will go up by $0.001 \%$. Though the total expenditure on produce has a positive significant influence on the marginal change, the magnitude of the impact is small. This indicates that although expenditures on produce do significantly influence willingness to buy new produce items, in reality, the magnitude of the impact may not be felt by the retailer. In addition, it was found that those who indicated that store availability was very important were $11 \%$ more likely to buy recently introduced produce or new to the market, compared with those who did not think about store availability. This suggests that an individual may 
Table 4. Logit model prediction estimates with their coefficients, SE, $t$-ratios, and marginal changes of ethnic Mexico and Puerto Rico origin populations' willingness to buy new ethnic produce items based on attributes (e.g., expenditure on total and ethnic produce, consumer perceptions, urban, family size, education, marital status, and ethnicity). Data collected via telephone survey conducted in the eastern United States between Apr. and May 2006.

\begin{tabular}{|c|c|c|c|c|}
\hline Variable $^{\mathrm{z}}$ & Coefficient & SE & $t$ Ratio & Marginal change \\
\hline Constant & -1.9772 & 0.3552 & -5.57 & - \\
\hline Eth_prod_exp ${ }^{y}$ & -0.0006 & 0.0003 & -2.08 & -0.0001 \\
\hline Tot_prod_expend ${ }^{\mathrm{x}}$ & 0.0006 & 0.0003 & 1.71 & 0.0001 \\
\hline Buy_eth_amer & -0.2277 & 0.2205 & -1.03 & - \\
\hline Store_avbl_imp ${ }^{\mathrm{y}}$ & 0.4296 & 0.2107 & 2.04 & 0.1063 \\
\hline Lang_imp ${ }^{\mathrm{x}}$ & -0.3707 & 0.2141 & -1.73 & -0.0915 \\
\hline Price_imp & 0.1727 & 0.2078 & 0.83 & - \\
\hline Selection_better & 0.1405 & 0.1998 & 0.70 & - \\
\hline Local_grown ${ }^{w}$ & 0.8402 & 0.2487 & 3.38 & 0.2070 \\
\hline Org_grown ${ }^{y}$ & 0.4034 & 0.2047 & 1.97 & 0.0994 \\
\hline Gm_prod ${ }^{y}$ & 1.1307 & 0.3882 & 2.91 & 0.2487 \\
\hline Cool_prod ${ }^{w}$ & 1.2729 & 0.2088 & 6.10 & 0.3026 \\
\hline Urban & 0.1571 & 0.2049 & 0.77 & - \\
\hline Family_size & -0.0014 & 0.0013 & -1.03 & - \\
\hline Less_12grade & 0.1140 & 0.1617 & 0.71 & - \\
\hline Hschool_grad & -0.1147 & 0.1617 & -0.71 & - \\
\hline Married & 0.0008 & 0.0008 & 1.00 & - \\
\hline Mexican $^{w}$ & 0.5073 & 0.2066 & 2.46 & 0.1244 \\
\hline
\end{tabular}

${ }^{2}$ Please refer to Table 2 for variable definitions.

'Significant at $P \leq 0.05$.

'Significant at $P \leq 0.10$.

wignificant at $P \leq 0.01$.

like to shop around and experiment with different new produce items.

Furthermore, those willing to buy locally grown ethnic produce items were found to be $21 \%$ more likely to buy ethnic produce that was recently introduced or new to the market than those who did not think about buying local produce items. This may be partially explained because consumers who are willing to purchase new ethnic items may perceive locally grown as being fresher or high quality compared with a nonlocal item. Those willing to buy organic ethnic produce were $10 \%$ more likely to buy ethnic produce that was recently introduced or new to the market than those who were not willing to buy organic ethnic produce. Certified organic produce is typically more expensive than nonorganic produce yet there is a demand for such organic ethnic produce (AldanondoOchoa and Almansa-Sáezl, 2009). With regard to genetically modified produce items, those willing to buy genetically modified ethnic produce were $25 \%$ more likely to buy ethnic produce that has been recently introduced than those who were not willing to buy genetically modified produce items. This behavior is very similar to consumers willing to buy organic produce items. Those willing to buy COOL produce were $30 \%$ more likely to buy ethnic produce that is recently introduced or new to the market than those were not willing to buy COOL produce items.

Out of nine significant variables, two negatively impacted willingness to buy ethnic produce that was recently introduced to the market. Those spending less per month on ethnic produce were less likely to buy new ethnic produce. Average monthly expenditure on ethnic produce, like average monthly total produce expenditure, is also a continuous variable, and the change in probability can be interpreted in a similar fashion. When the expenditure on ethnic produce per month goes down by a dollar, likelihood of buying newly introduced products declined by $0.001 \%$. A lower monthly expenditure on ethnic produce possibly indicates that the consumer is less concerned about ethnic produce, which may relate to less interest in buying new ethnic produce items. Finally, respondents who indicated that Spanish-speaking store employees are important for them in terms of their decision to purchase ethnic produce are $9 \%$ less likely to buy ethnic produce that is recently introduced or new to the market than those who thought otherwise.

\section{Conclusions}

This study analyzed the influence of socioeconomic characteristics on the likelihood of Latino ethnic consumers' willing to buy ethnic produce that has been recently introduced or new to the market. The findings may be helpful for market intermediaries and farmers to better understand Latino consumers' perceptions and the factors that drive the willingness to buy ethnic produce. Targeting characteristics such as respondent's expenditure on total produce and ethnic produce, perceptions such as the importance of store availability, Spanishspeaking employees, and willingness to buy locally grown, organic, genetically modified produce, and COOL produce items were found to increase the likelihood of Mexican consumers' willingness to buy new ethnic produce item compared with Puerto Rican ethnic consumers. The model shows that there is a significant positive impact on the purchase of new ethnic products when accompanied by adequate and accessible information. The results will also be useful to value chain market intermediaries such as wholesalers and retailers to better understand the perceptions and preferences of those consumers within this niche market. Market intermediaries and farmers could use eastern U.S. population information by state to target specific ethnic group (Table 1). In addition, the U.S. Census Bureau provides population distribution by ethnicity, township, county, and congressional district across the United States at no cost.

Although this study had several significant variables that may be useful for ethnic consumer targeting and implementing marketing strategies, caution should be exercised when applying such findings. Given that the socioeconomic characteristics of the sample area is characterized by a dense population, with relatively more ethnic Mexicans and an overall higher produce expenditure may be specific to eastern United States and may not apply elsewhere. However, further research are needed to explore why Puerto Rican consumers are less likely to buy ethnic produce that is recently introduced or new to the market because this might provide valuable information in introducing new ethnic produce item in ethnic market place. In addition, the future research on 
ethnic markets should include other parts of United States as that will determine the predictability of these findings for larger and more encompassing markets and provide more specific information to the agricultural community to ensure they produce those products of higher interest to the Latino communities.

\section{Literature cited}

Aldanondo-Ochoa, A.M. and C. Almansa-Sáezl. 2009. The private provision of public environment: consumer preferences for organic production systems. Land Use Policy. 26:669-682.

Asp, E. 1999. Factors affecting food decisions made by individual consumers. Food Policy. 24:287-294.

Bhugra, D. 1999. Cultural identity and its measurement: A questionnaire for Asians. Intl. Rev. Psychiatry. 11:244-250.

Govindasamy, R., A. Nemana, V.S. Puduri, and K. Pappas. 2006. Ethnic produce marketing in the mid-Atlantic states: Consumer shopping patterns and willingness-to-pay analysis. Choices 21:237-241.

Govindasamy, R., R. VanVranken, W. Sciarappa, A. Ayeni, V.S. Puduri, K. Pappas, J.E. Simon, F. Mangan, M. Lamberts, and G. McAvoy. 2007a. Demographics and the marketing of Asian and Hispanic produce in the eastern coastal U.S.A. New Jersey Agr. Expt. Sta. Rpt. P-02903-2-07. 20 July 2009. <http://www.dafre.rutgers.edu/ documents/ramu/nri_ethnic_crops_results_ nov2007.pdf/>.

Govindasamy, R., W. Sciarappa, V.S. Puduri, R. VanVranken, A. Ayeni, K. Pappas, J.E. Simon, F. Mangan, M. Lamberts, and G. McAvoy. 2007b. A market driven approach to ethnic crop production for the U.S. east coast, p. 261-273. In: J. Janick and A. Whipkey (eds.). Creating markets for economic development of new crops and new uses. Proc. 6th New Crops Symp. ASHS Press, Alexandria, VA.

Gujarati, D.N. 1992. Essentials of econometrics. 2nd ed. McGraw-Hill, New York.

Guzman, B. 2001. The Hispanic Population: Census 2000 Brief. 22 Nov. 2009. <http://www.census.gov/prod/2001pubs/ c2kbr01-3.pdf>.

Jekanowski, M.D., D.R. Williams, II, and W.A. Schiek. 2000. Consumers' willingness to purchase locally produced agricultural products: An analysis of an Indiana survey. Agr. Resource Econ. Rev. 29:43-53.

Nayga, R.M., Jr. 1995. Determinants of U.S. household expenditures on fruit and vegetables: A note and update. J. Agr. Appl. Econ. 27:588-594.
Perry, M.J. and P.J. Mackum. 2001. Population Change and Distribution 1990 to 2000: Census 2000 Brief. 22 Nov. 2009. <http://www.census.gov/prod/200lpubs/ c2kbr0l-2.pdf $>$.

Pindyck, R. and D. Rubinfeld. 1991. Econometric models and economic forecasts. 3rd ed. McGraw-Hill, New York.

Robinson, R. and C. Smith. 2002. Psychosocial and demographic variables associated with consumer intension to purchase sustainably produced foods as defined by the Midwest Food Alliances. J. Nutr. Educ. Behav. 34:316-325.

Tubene, S. 2001. Agricultural and demographic changes in the Mid-Atlantic region: Implications for ethnic and specialty produce. Univ. of Maryland Coop. Ext. Fact Sheet 793.

U.S. Census Bureau. 2001. Profiles of general demographic characteristics. 2000 Census of population and housing. U.S. Census Bureau, Washington, DC.

U.S. Census Bureau. 2008. National population projections. U.S. Census Bureau, Washington, DC.

U.S. Census Bureau. 2009. American community survey 2005-2009. U.S. Census Bureau, Washington, DC. 